\title{
POSSIBILITIES OF THE APPLICATION OF CARBONATE ROCKS OF THE RAIKKÜLA FORMATION (SILURIAN, ESTONIA)
}

Abstract. The Raikküla Formation consists of a great variety of limestones and dolomites. On the basis of the spatial distribution of different rock types, four areas can be distinguished. They have different prospects of revealing resources of carbonate rocks. 1. The Western area, where limestones occur, is prospective for the production of lime and construction materials. 2. The Rapla area has no prospects for revealing resources of limestone or dolomite of constant mineral composition. Both limestone and dolomite can be used for the production of construction materials. 3. The Paide area is represented by dolomites only and it is promising for revealing sizeable resources for the industry of construction materials. There are no preconditions for revealing resources of chemically pure dolomites in this area as argillaceous interlayers occur throughout the whole section. 4. The Eastern area, where the Raikküla Formation is represented by argillaceous dolomite and mainly cryptocrystalline (less bioclastic) limestone, is promising for the industry of construction materials. A very special type of bioclastic marble-like limestone (the so-called "Kalana marble") lies south of Põltsamaa. It can be used (and has been used) for lime and glass production and for small decorative and sculptural units.

Depending on the variety of rock types in the sequence, selective mining and comprehensive utilization have to be practised on the whole outcrop of the Raikküla Formation.

The Raikküla Regional Stage embraces the central part of the Estonian Llandovery. It falls into Raikküla and Saarde formations (Решения ...., 1987). On the belt of outcrops, only the former occurs. The belt of outcrops proceeds from the southern part of Hiiumaa Island through central Estonia to Jõgeva (Fig. 1). The thickness of the covering Quaternary sediments is less than $5 \mathrm{~m}$ on most of the outcrop; the thickness of the Raikküla Formation reaches $40 \mathrm{~m}$.

The Raikküla Formation consists of a great variety of limestone, dolomitized limestone, and dolomite of mainly horizontal-bedding, less commonly of wavy- and nodular-bedding structure. They represent the most shallow-water sediments of the Raikküla age of the Baltic Silurian basin, preserved after the post-Silurian denudation. Accordingly, alternation of different types of rock in the sequence is common and the content of terrigenous material is smaller than in the subsurface areas.

The stratigraphic subdivision of the Raikküla Regional Stage and the problem of its upper boundary have been discussed in numerous works (Решения..., 1987; Силур ..., 1970; Einasto and Perens, 1985). The present work is based on the unified regional stratigraphic scheme accepted in 1984 by the Stratigraphic Conference on Ordovician and Silurian of the East-European Platform (Решения..., 1987). The cyclic nature of the sections, the intricate spatial interrelations of the rock types, and the lack of generally accepted local stratigraphic subdivisions (units) complicate the establishment of the exact stratigraphic position of the investigated deposits in the cross-section of the Raikküla Regional Stage.

* Eesti Teaduste Akadeemia Geoloogia Instituut (Institute of Geology, Estonian Academy of Sciences). EE0105 Tallinn, Estonia pst. 7. Estonia. 


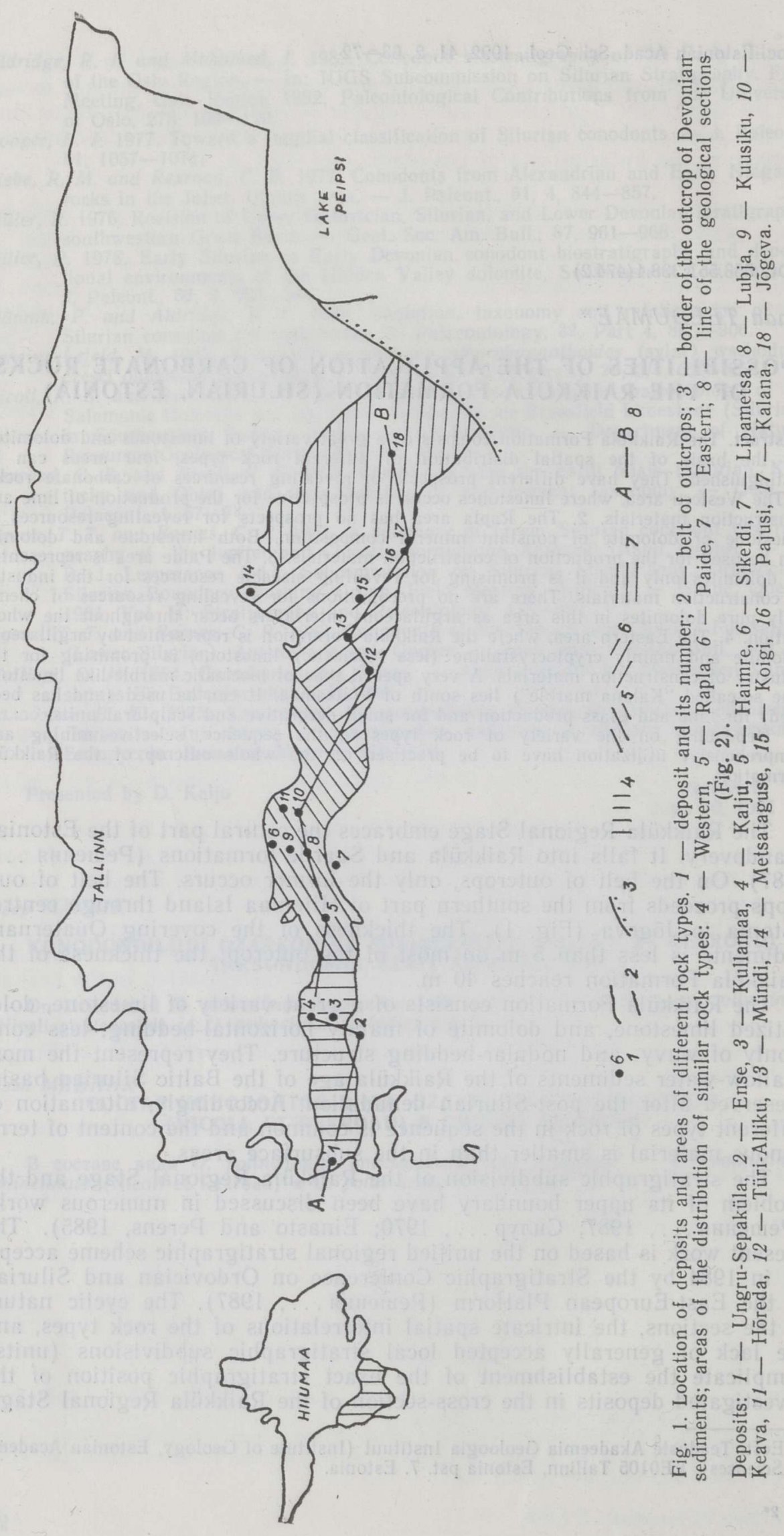




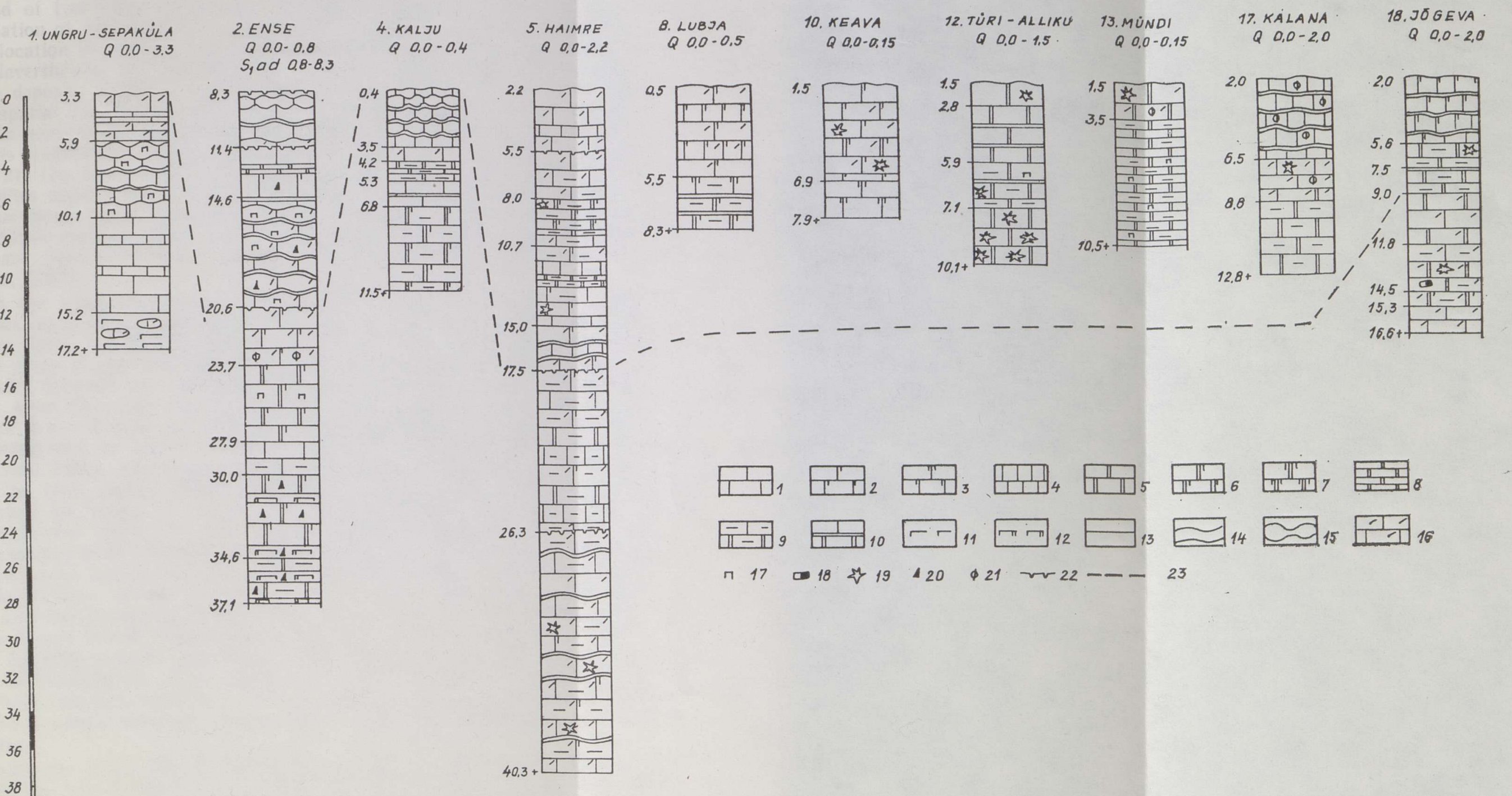

Fig. 2. Geological sections of the deposits of the Raikküla Formation. Numbers of deposits correspond to those in the Table and Fig. 1.

1 - limestone in general; 2 - dolomitic limestone; 3 - highly dolomitic limestone; 4 - aphanitic (cryptocrystalline) limestone; 5 - dolomite in general; 6 - calcitic dolomite; 7 - highly calcitic dolomite; 8 - microlaminated dolomite; 9 - argillaceous dolomite; 10 - limestone, dolomite with thin clayey intercalations; 11 - calcareous marl; 12 - dolomitic marl; 13 - horizontal bedding; 14 - wavy bedding; 15 - nodular and seminodular bedding; 16 - fragments of fossils (skeletal detritus); 17 - pyrite mottles, finegrained pyrite; 18 - crystals of sphalerite; 19 - cavities; 20 - bitumen; 21 - silicification; 22 - hardground; 23 - boundary between the Upper and the Lower part of the Raikküla Formation. 
On the whole outcrop in the sequence, two maximums of the content of terrigenous material can be stated (Силур ..., 1970): one in the lower part and the other in the middle. The latter divides the Raikküla Formation into two parts. The Upper and Lower parts can be considered as cyclo-stratigraphical units (Nestor, 1990). In the present work, the stratigraphical position of deposits was fixed with the kind help of $\mathrm{H}$. Nestor according to this division (Fig. 2). It has to be admitted that on the background of two main shallowing-up cycles, the lower-rank local cyclic alternation of rock types can be noticed. The number of local cycles and their location in the section vary and they cannot be correctly correlated yet. Nevertheless, the data obtained from the prospecting and exploring of the deposits enable to estimate properties of different rock types and their spatial distribution with regard to the possibilities of their application. In general, in the western part limestones with corals and stromatoporoids predominate over dolomites; in the eastern part dolomites prevail (Fig. 2). The primary or secondary origin of dolomites is still debatable. Dolomites usually contain relicts of fossils and their secondary origin is obvious. Some layers of microlaminated argillaceous dolomites at Haimre and Mündi deposits (Figs. 1 and 2) have no signs of relict structures and they are considered to be of primary lagoonal origin (Einasto and Perens, 1985).

On the whole outcrop of the Raikküla Formation, numerous small quarries occur where local people have made use of carbonate rocks since ancient times. The most well-known quarries of the past belong nowadays to the areas of explored deposits (Fig. 1). So the Pusku quarry (UngruSepaküla deposit) was exploited in the 13th century (Einasto and Matve, 1989) when limestone was used for the building of the Haapsalu Castle Church. Later it was used for building manor-houses (Ungru, etc.) and producing lime for export to Finland and St. Petersburg (Eichwald, 1843; Минквиц, 1852). The Orgita quarry near the Haimre deposit is known from the 14th century (Eichwald, 1843). Dolomite of the Orgita quarry was used for laying the walls of the Märjamaa Church and in Tallinn for sculptural units (Oleviste Church, Suur Rannavärav, etc.). It was also exported to St. Petersburg. The history of the Kalana quarry (Kalana deposit) dates back to the 13th century when the Põltsamaa Castle Church was built. Later, in the 18 th century, its limestone was used as lime kiln feed and for producing mirrors and glass at the Rõika-Meleski works (Einasto and Matve, 1989). The Mündi quarry (Mündi deposit) is known from the 13 th century (Минквиц, 1852). Dolomite from this quarry was used for building the Paide Castle and later for many other buildings. In the 1930s, dolomite was mined in cave (Luha, 1946), which may be considered a unique example of underground mining of carbonate rocks in Estonia.

Until the 1950s, the utilization of carbonate rocks of the Raikküla Formation was based on small local quarries whose reserves had not been explored or estimated. Then the geologic exploration and prospecting began and carbonaceous rocks were estimated according to the technical requirements of the industry of the USSR. Up to now 18 deposits and promising areas have been revealed (Table, Fig. 1). Only two of them Kalana and Ungru-Sepaküla - are exploited. The other explored deposits have not been introduced into industry. The main cause of this situation is the technology of machine-mining used by the industry. The blasting of $5-6 \mathrm{~m}$ benches eliminates any possibility of selective extraction of layers of different types of rocks each of which could find a special application. In mass production all layers with different properties become a heterogenous mixture, suitable for road metal (aggregate) of low quality (pressure resistance 40-60 MPa) only. 


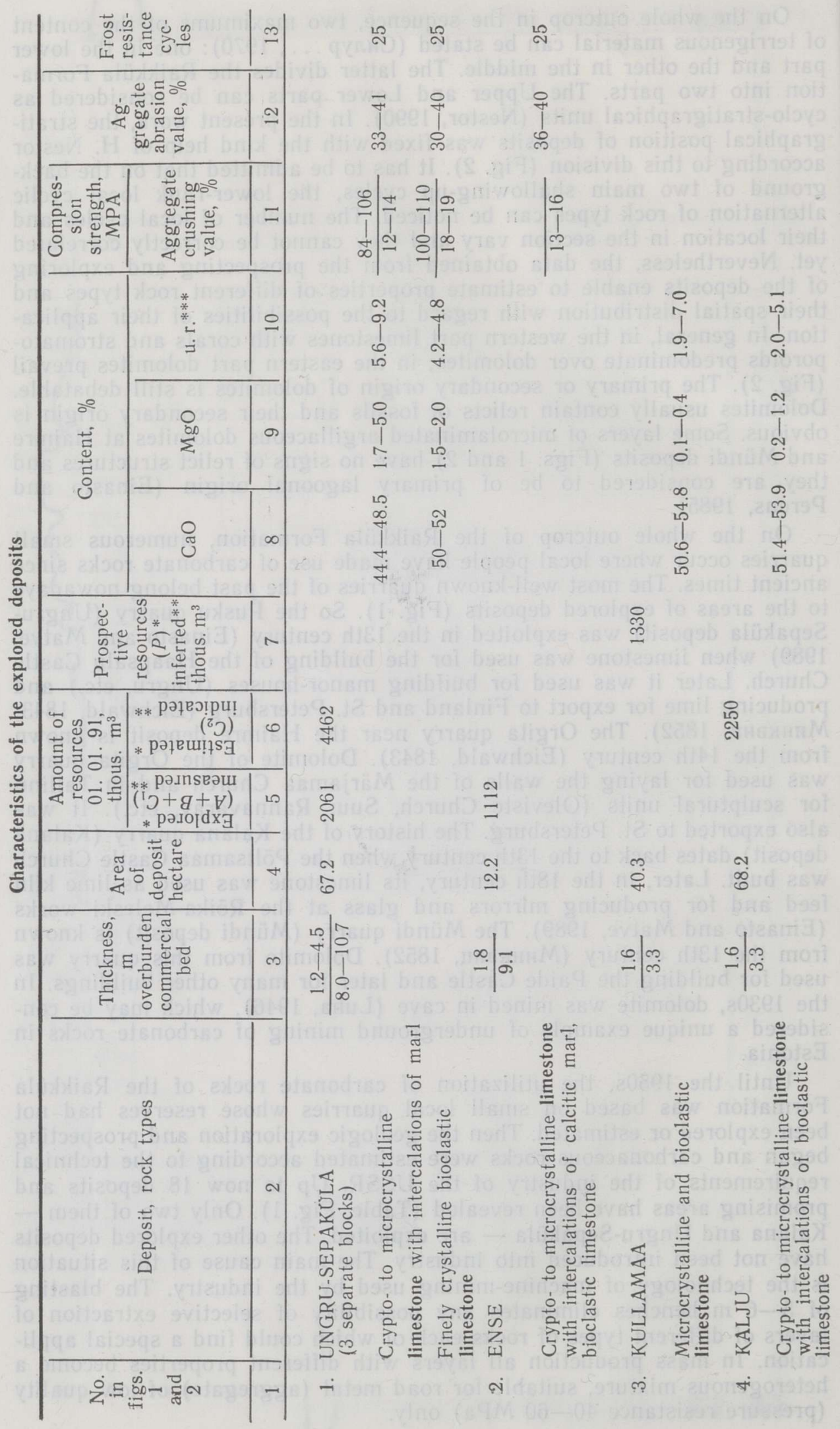




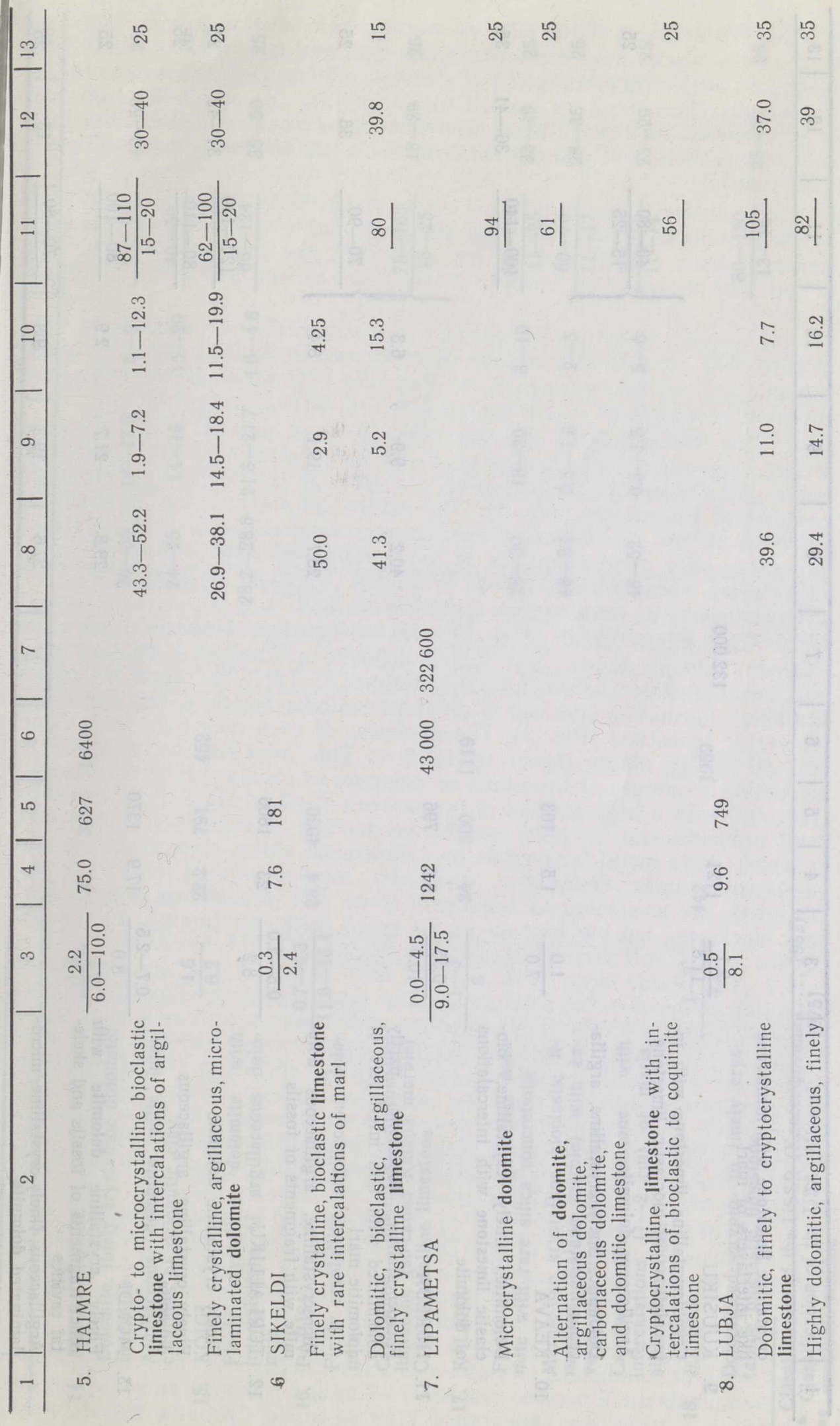




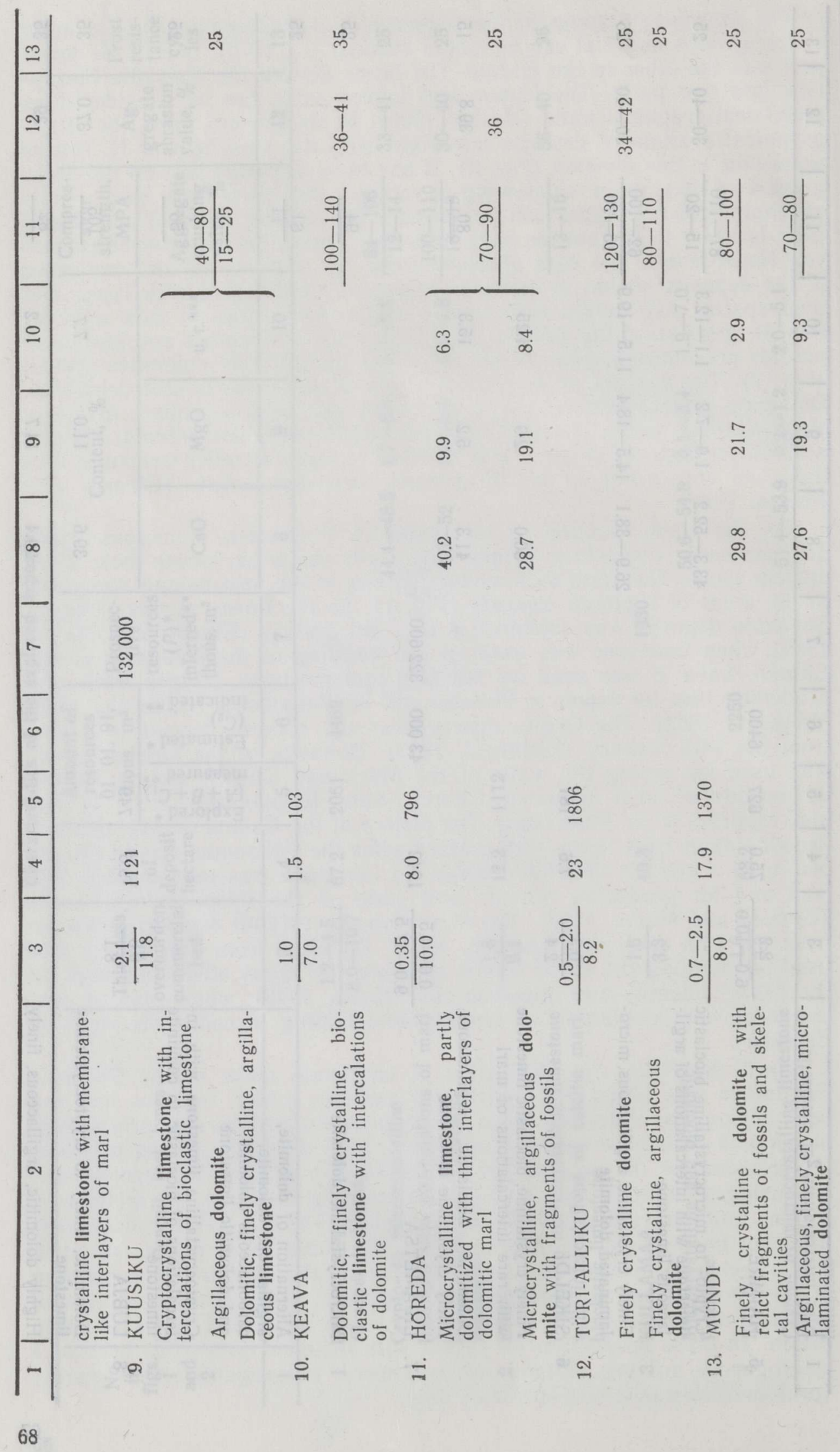




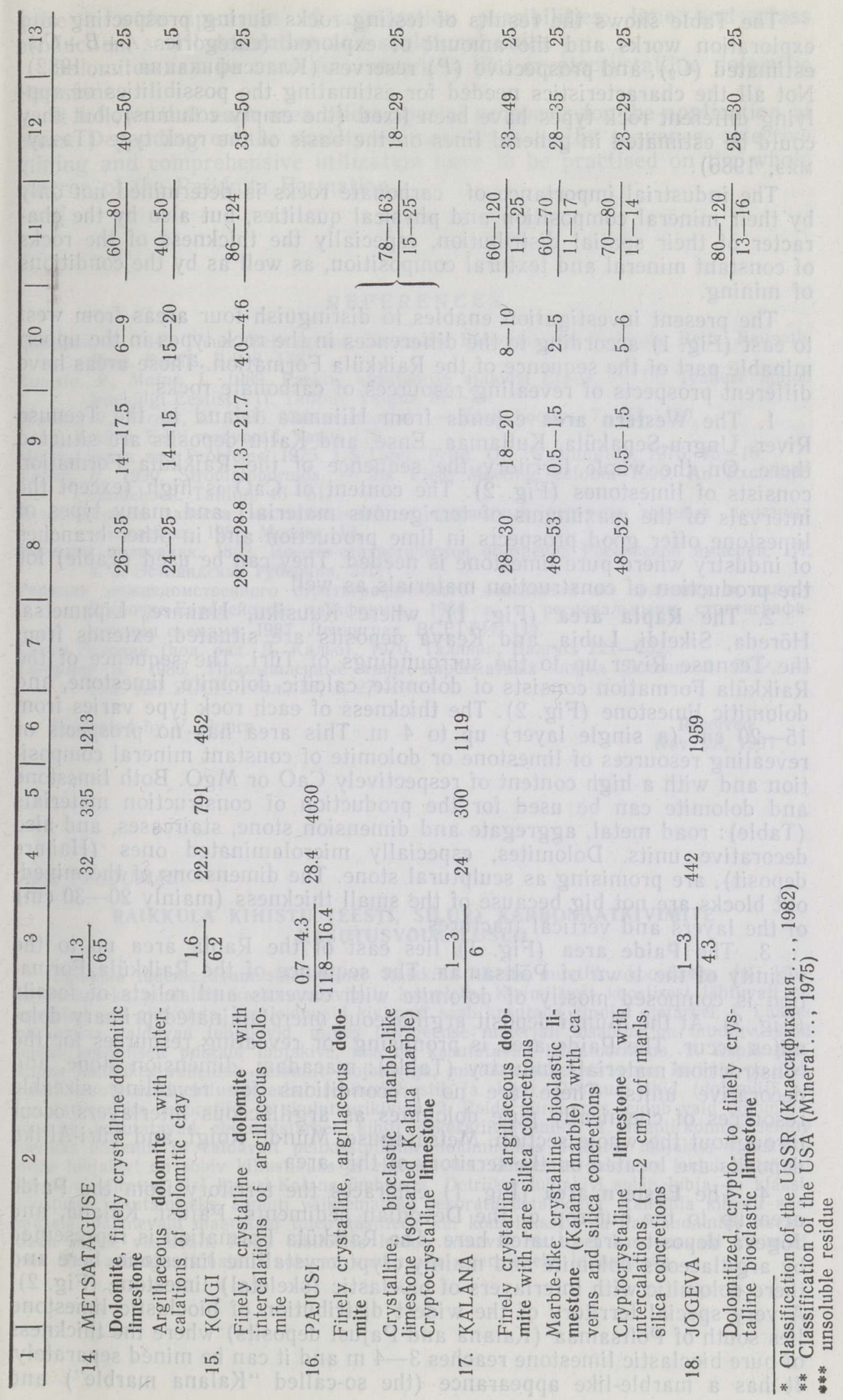


The Table shows the results of testing rocks during prospecting and exploration works and the amount of explored (categories $A+B+C_{1}$ ), estimated $\left(C_{2}\right)$, and prospective $(P)$ reserves (Классификация . . , 1982). Not all the characteristics needed for estimating the possibilities of applying different rock types have been fixed (the empty columns), but they could be estimated in general lines on the basis of the rock type (Тээдумяэ, 1986).

The industrial importance of carbonate rocks is determined not only by their mineral composition and physical qualities, but also by the character of their spatial distribution, especially the thickness of the rocks of constant mineral and textural composition, as well as by the conditions of mining.

The present investigation enables to distinguish four areas from west to east (Fig. 1) according to the differences in the rock types in the upper, minable part of the sequence of the Raikküla Formation. These areas have different prospects of revealing resources of carbonate rocks.

1. The Western area extends from Hiiumaa Island to the Teenuse River. Ungru-Sepaküla, Kullamaa, Ense, and Kalju deposits are situated there. On the whole territory the sequence of the Raikküla Formation consists of limestones (Fig. 2). The content of $\mathrm{CaO}$ is high (except the intervals of the maximums of terrigenous material) and many types of limestone offer good prospects in lime production and in other branches of industry where pure limestone is needed. They can be used (Table) for the production of construction materials as well.

2. The Rapla area (Fig. 1), where Kuusiku, Haimre, Lipametsa, Hõreda, Sikeldi, Lubja, and Keava deposits are situated, extends from the Teenuse River up to the surroundings of Türi. The sequence of the Raikküla Formation consists of dolomite, calcitic dolomite, limestone, and dolomitic limestone (Fig. 2). The thickness of each rock type varies from $15-20 \mathrm{~cm}$ (a single layer) up to $4 \mathrm{~m}$. This area has no prospects of revealing resources of limestone or dolomite of constant mineral composition and with a high content of respectively $\mathrm{CaO}$ or $\mathrm{MgO}$. Both limestone and dolomite can be used for the production of construction materials (Table): road metal, aggregate and dimension stone, staircases, and also decorative units. Dolomites, especially microlaminated ones (Haimre deposit), are promising as sculptural stone. The dimensions of the minedout blocks are not big because of the small thickness (mainly $20-30 \mathrm{~cm}$ ) of the layers and vertical fractures.

3. The Paide area (Fig. 1) lies east of the Rapla area up to the vicinity of the town of Põltsamaa. The sequence of the Raikküla Formation is composed mostly of dolomite with caverns and relicts of fossils (Fig. 2). At the Mündi deposit argillaceous microlaminated primary dolomites occur. The Paide area is promising for revealing resources for the construction materials industry (Table): macadam, dimension stone, and decorative units. There are no preconditions for revealing sizeable resources of chemically pure dolomites as argillaceous interlayers occur throughout the whole section. Metsataguse, Mündi, Koigi, and Türi-Alliku deposits are located on the territory of this area.

4. The Eastern area (Fig. 1) embraces the territory from the Paide area up to the outcrop of the Devonian sediments. Pajusi, Kalana, and Jõgeva deposits are situated here. The Raikküla Formation is represented by argillaceous dolomite and mainly cryptocrystalline limestone, here and there dolomitic with interlayers of bioclastic (skeletal) limestone (Fig. 2). A very special territory of the widest distribution of bioclastic limestone lies south of Põltsamaa (Kalana and Pajusi deposits) where the thickness of pure bioclastic limestone reaches $3-4 \mathrm{~m}$ and it can be mined separately. It has a marble-like appearance (the so-called "Kalana marble") and 
quite a wide spectrum of application possibilities: lime and glass production, small decorative and sculptural units.

Dolomites can be used for macadam like cryptocrystalline dolomitic limestone.

It follows that each area offers special prospects for the application of rocks. Depending on the variety of rock types in the sequence, selective mining and comprehensive utilization have to be practised on the whole outcrop of the Raikküla Formation.

\section{REFEREN CES}

Eichwald, E. 1843. Neuer Beitrag zur Geognosie Estlands und Finlands. Beitr. Kenneth. Russ. Reichs, Bd. 8, 138.

Einasto, R., Matve, L. 1989. Paekivi kasutamise ajaloost Eestis. - In: Teaduse ajaloo lehekülgi Eestist VII. Tallinn, Valgus, 57-75.

Einasto, R., Perens, H. 1985. Kalana marmor. - Eesti Loodus, 7, 453-459.

Luha, A. 1946. Eesti maavarad. Tartu, 176.

Mineral Facts and Problems. 1975. US Govt. Print. Off. Washington, 1976. 15-18.

Nestor, H. 1990. Stromatoporoids. - In: Field Meeting Estonia 1990. An Excursion Guidebook. Tallinn, 46-51.

Классификация запасов месторождений и прогнозных ресурсов твердых полезных ископаемых. 1982. Москва, 13.

Минквиц, полковник. 1852. Военно-статистическое обозрение Российской империи, III, ч. 3. Эстляндская губерния, 370 .

Решения межведомственного стратиграфического совещания по ордовику и силуру Восточно-Европейской платформы, 1984 г. с региональными стратиграфическими схемами. 1987. Ленинград, ВСЕГЕИ, 114.

Силур Эстонии (под. ред. Д. Кальо). 1970. Таллинн, Валгус, 221-232.

Тәэдумяэ A. 1986. Промышленные типы карбонатных пород Эстонской ССР. Изв. АН ЭССР. Геол., $35,1,27-34$.

Presented by V. Puura

Received

Nov. 28, 1991

\section{Aada TEEDUMÄE}

\section{RAIKKULA KIHISTU (EESTI, SILUR) KARBONAATKIVIMITE KASUTUSVÓIMALUSED}

Raikküla lademe avamusalal esineb Raikküla kihistu muutliku koostisega (nii läbilōikes kui ka pindalal) karbonaatkivimite kompleks. Kivimilisest koostisest lähtuvalt on eristatud neli piirkonda, kus leiduvaid kivimeid saab kasutada kindlal otstarbel. 1. Läänepiirkonnas valdavad lubjakivid, milles terrigeense materjali sisaldus on muutuv, kuid leidub keemiliselt puhtaid lubjakive, mis on kasutatavad lubjatoormena. 2. Rapla piirkonna läbilōikes vaheldub dolomiit lubjakiviga, mistōttu selle piirkonna kivimid on üldjuhul kasutatavad ehitusotstarbel (ehituskillustik ja -kivi). Uksikud kihid (dolomiit) on kasutatavad ka dekoratiiv- ja skulptuurikivina. 3. Paide piirkonnas leidub vaid dolomiite, mis on kasutatavad ehitusotstarbel, kihiti dekoratiivkivimina. 4. Idapiirkonnas leiduv savikas dolomiit ja valdavalt peitkristalliline dolomiidikas detriitse lubjakivi vahekihtidega lubjakivi on sobiv killustikuks ja ehituskiviks. Suuremas paksuses leidub detriitset lubjakivi piiratud alal Pajusi-Kalana ümbruses. Detriitne lubjakivi sobib lubja- ja klaasitööstuses kasutamiseks, samuti väiksemateks dekoratiivdetailideks. Raikküla kihistu avamusalal paiknevaid maardlaid tuleb käsitleda kui kompleksseid ja kaevandamine kavandada sellele vastavalt. Kogu läbilõikes leidub erineval otstarbel kasutatavaid kivimeid, mis ühes astangus lōhațuna sobivad vaid madalamargiliseks killustikuks. 


\section{ВОЗМОЖНОСТИ ИСПОЛЬЗОВАНИЯ КАРБОНАТНЫХ ПОРОД РАИККЮЛАСКОИ СВИТЫ (СИЛУР, ЭСТОНИЯ)}

На выходе пород райккюлаской свиты обнажается сложный комплекс известняков и доломитов, содержащих в изменчивом количестве терригенный материал. На фоне обшей изменчивости выделено четыре региона, в пределах которых породы однотипны по цели использования. 1. Западный регион сплошь представлен известняками, в том числе и химически чистыми, пригодными для производства извести. 2. Раплаский регион сложен переслаивающимися известняками и доломитами, которые могут быть использованы в строительстве (щебень, строительный камень и т. д.). Местами встречаются разновидности доломитов, пригодных для декоративных целей. 3. Пайдеский регион характеризуется развитием доломитов разной глинистости, которые в преобладаюшем большинстве применимы для производства щебня и строительного камня. Микрослойчатые доломиты (Мюнди) перспективны и в качестве сырья для декоративных целей. 4. Восточный регион представлен глинистыми доломитами и доломитизированными скрытокристаллическими известняками с прослоями детритового известняка, представляющими сырье для производства щебня и строительного камня. Большей мощностью $(3-4$ м) детритового известняка характеризуется окрестность Паюзи-Калана. Детритовый известняк отличается химической чистотой, имеет вид «под мрамор» и может быть использован как сырье для производства извести и стекла, а также в качестве декоративного камня.

Все месторождения райккюлаской свиты следует рассматривать как комплексные, ибо в разрезе присутствуют интервалы пород разного назначения, и это должно быть учтено при разработке месторождений. 